\title{
Some applications of natural polymeric materials in oilfield operations: a review
}

\author{
Jimoh K. Adewole ${ }^{1,2}\left(\mathbb{D} \cdot\right.$ Kabir B. Muritala ${ }^{3}$
}

Received: 9 July 2018 / Accepted: 16 February 2019 / Published online: 25 February 2019

(c) The Author(s) 2019

\begin{abstract}
Naturally occurring macromolecular materials can be turned to value-added resources for applications in oil and gas production. The use of these materials has become necessary due to the environmental requirements that are associated with the disposal of oilfield chemicals after usage, sustainability of raw materials for producing the chemicals, and the need for reducing the overall cost of hydrocarbon production. This review presents the applications of natural polymers in oilfield operations including drilling, enhanced oil recovery, and water and gas shut-off.
\end{abstract}

Keywords Oilfield chemicals · Drilling fluid $\cdot$ Enhanced oil recovery $\cdot$ Membrane composite $\cdot$ Macromolecules $\cdot$ Water and gas shut-off

\section{Introduction}

Naturally occurring polymeric materials consist of many components including cellulose, lignin, hemicellulose, starch, protein, fats and others (Murr 2015; Olatunji 2016). Over the years, the use of these components has been limited to their pure forms as individual material. To obtain and use these components in their pure forms, naturally occurring multicomponent materials are exposed to certain processes involving extraction, fractionation, and other forms of physical and chemical treatments ( $\mathrm{Li}$ et al. 2016). The recent trend is tending towards minimization of these refining and purification processes and using the materials as they are (crude forms). The little processing requirement that is needed in this case is size reduction, which is often achieved by grinding the materials or using chemical or hydrothermal treatment.

Jimoh K. Adewole

adekayojih@kfupm.edu.sa

1 Process Engineering Department, International Maritime College, Sohar, Oman

2 Center for Integrative Petroleum Research, College of Petroleum Engineering and Geosciences, King Fahd University of Petroleum and Minerals, Dhahran 31261, Saudi Arabia

3 Chemical and Polymer Engineering Department, Lagos State University, Lagos, Nigeria
What seems to be particularly new in the use of the naturally occurring materials is the reduction in the number of steps that are needed for these materials to be useful for their targeted applications. Since the inception of the oil and gas industry, many natural polymers have been used. Examples include cellulose, starch, and lignin (Kraak 1992). Some of these polymers were either used as extracted in their pure or ultra-pure forms or used after little modification (examples are cellulose and carboxymethyl cellulose) (Biswas et al. 2014). Much more elaborate processes aimed at optimizing some specific properties were later carried out on some of these materials. Many of these post-purifications and treatments result in a multiple numbers of processing steps which cause an increase in the cost of production. Certain operations in the oil and gas industry do not require the use of ultra-pure chemicals. For this reason, attention has turned to using these polymers in their naturally occurring composite forms with little or no modification. This idea emanates from the nature of formulations used for many of the oil and gas industry operations. Many of the intrinsic components of these naturally occurring materials are also needed as additives. For example, Table 1 contains some of the additives used in the preparation of drilling fluid formulations. In certain instance, the formulation contains two or more natural polymers that are added to the based materials to improve some of the performance properties of the formulations.

There are some materials whose large percentage of their inherent components is a combination of the materials in 
Table 1 Renewable materials for drilling fluid applications

\begin{tabular}{lll}
\hline Drilling fluid additives & Function & Possible source \\
\hline Xanthan gum & Thermal stability/viscosity control & Modified biomaterials \\
Starch/cellulose & Viscosifiers/clay stabilizer & Natural polymers \\
Lignin/its derivatives & Viscosity and gel strength control & Natural/modified biomaterials \\
Quebracho & Dispersant & Heartwood \\
Polyol & Shale inhibitor & Biomaterials \\
Fatty acids & Puffer & Bio-derived \\
Scleroglucan & Viscosifiers & Bio-derived \\
Guar gum & Thickener/shear thinner & Bio-derived \\
\hline
\end{tabular}

Table 1. Bagasse, for instance, contains $55 \%$ cellulose, and $24 \%$ lignin. This makes bagasse a very good candidate for use as rheological properties modifier and wellbore stabilizer. Therefore, today's trends on the use of natural polymers are tending towards the utilization of renewable materials in their raw forms. At the same time, extensive researches into the effects of the minor component on the performance of the formulations into which these raw (the naturally occurring multicomponent) materials have been added are very crucial.

Globally, over 140 billion metric tons of these natural polymers are generated in form of waste from agricultural, domestic and industrial processing activities every year (Mohlala et al. 2016). Making use of this enormous amount of materials in upstream operations of the oil and gas industries will provide a better and more economical alternative for waste management and environmental pollution. It will facilitate the integration of green chemistry into the production of oilfield chemicals. By doing so, oilfield production subsectors will be able to minimize waste through efficient utilization of raw materials, mitigate health, safety, and environmental issues by avoiding the use of toxic and hazardous solvents (Sheldon 2014). This review, therefore, presents an overview of some bio-based macromolecular materials and their applications as oilfield chemicals. The necessary steps in use of these polymers are: identification of the sources of the industrial by-products, knowledge of their chemical compositions, and development of methods for making multifunctional oilfield chemicals from suitable by-products.

On a general note, the cost of producing a chemical can be brought down by reducing the number of sequential treatments that the chemical will have to undergo before becoming a finished product. For this reason, it can be inferred that materials with little or no processing are cheaper. This review will, therefore, focus on publications that report the use of these materials in their raw form or those with little processing. Hydrocarbon recovery involves varieties of processes and operations. To keep the scope of this write up within a manageable level, the review will only cover specific operations which include drilling, enhanced oil recovery, and water and gas control.

\section{Composition of some naturally occurring multicomponent materials}

This review will not be complete without presenting some overview of the composition of some of the polymers that are considered in this paper. Therefore, this section is focused on the major as well as the minor component of these macromolecular materials (date pit, rice husk, cassava starch, protein isolate, wood, and sugarcane bagasse). The description of the methods of the compositional analysis that leads to this result and detailed description of these macromolecules is very important and is also presented in this paper.

The complete biomass compositional analysis of natural polymeric materials or biomass has been performed using various methods (Templeton et al. 2010). One of the first methods was developed between 1883 and 1913 by Fleschsig in 1883, Klason in 1906, Ost and Wilkening in 1912, and Konig and Rump in 1913. The method employed two-stage sulfuric acid hydrolysis for the analysis of lignin content in wood biomass. Many researchers have worked to improve the hydrolysis method. In addition to wood lignin, numerous contributions by researchers resulted in the use of the hydrolysis method for the analysis of wood sugar. The method was later extended to food, dietary fiber, and other kinds of biomass. Most recently, 
Table 2 Average composition of lignocellulose materials (Gandini 2008; Singh et al. 2008; Adewole and Sultan 2013; Fiorelli et al. 2014; Aboulrous et al. 2016)

\begin{tabular}{|c|c|c|c|c|c|c|c|}
\hline Polymers & Moisture (\%) & Cellulose & Hemicellulose & Lignin & Fat & Ash & Protein \\
\hline Date pit & 10.2 & $20.18-56.7$ & $23.3-55.5$ & $14.7-23.2$ & $5.02-12.67$ & $1.1-5.3$ & 5.67 \\
\hline Soy protein isolates & 4.7 & - & - & - & $<0.1$ & - & 92.8 \\
\hline Nutshell & - & $25-30$ & $25-30$ & $30-40$ & - & - & - \\
\hline Corn cobs & - & 45 & 35 & 15 & - & - & - \\
\hline Grasses & - & $25-40$ & $35-40$ & $10-30$ & - & - & - \\
\hline Bagasse & 5 & $50.47-55$ & $25-30.56$ & $10.74-28.0$ & - & 4 & - \\
\hline Sawdust & 4.8 & 58.2 & - & 28.4 & - & 0.21 & - \\
\hline Peanut hulls ${ }^{\mathrm{a}}$ & 8 & $25-44.01$ & 7.70 & 31.16 & 1 & 2 & - \\
\hline Coconut fiber & $6-10$ & 56.69 & 16.64 & 25.11 & - & - & - \\
\hline
\end{tabular}

${ }^{a}$ Crude fiber is $60 \%$

Table 3 Average mineral composition of some naturally occurring multicomponent polymers (Adewole and Sultan 2014; Wajheeuddin and Hossain 2017)

\begin{tabular}{lcl}
\hline Components & Date pit (mg/100 g of oil) & Grasses (wt $)$ \\
\hline Potassium & 255.43 & 0.67 \\
Magnesium & 62.78 & 0.21 \\
Calcium & 48.56 & 1.10 \\
Phosphorus & 41.33 & - \\
Silicon & 0.37 & 0.3 \\
\hline
\end{tabular}

the National Renewable Energy Laboratory (NREL) has developed a method that can achieve complete biomass compositional analysis (Sluiter et al. 2010). The developed suite of laboratory analytical procedures (LAPs) by NREL is capable of a complete compositional analysis of woody feedstocks and herbaceous materials. Biomass components are determined in the form of total solids, total dissolved solids, ash content, extractives, protein, structural carbohydrates, and lignin (Sluiter et al. 2010). Researchers have also investigated other methods. One of these investigations was done on the elemental composition (Vassilev et al. 2010). The results of this work revealed that $\mathrm{C}, \mathrm{O}$, $\mathrm{H}, \mathrm{N}, \mathrm{Ca}, \mathrm{K}, \mathrm{Si}, \mathrm{Mg}, \mathrm{Al}, \mathrm{S}, \mathrm{Fe}, \mathrm{P}, \mathrm{Cl}, \mathrm{Na}, \mathrm{Mn}$, and Ti are commonly found in biomass (Vassilev et al. 2010). The composition of the ash contained in biomass has also been investigated. Results showed that the ash contains $\mathrm{CaO}$, $\mathrm{SiO}_{2}, \mathrm{~K}_{2} \mathrm{O}, \mathrm{MgO}, \mathrm{Al}_{2} \mathrm{O}_{3}, \mathrm{P}_{2} \mathrm{O}_{5}$, and $\mathrm{Al}_{2} \mathrm{O}_{3}$ (Vassilev et al. 2010).

Research results published in the literature revealed that naturally occurring multicomponent materials have some properties that qualify them to be used as viscosifying agents, corrosion inhibitor, fluid loss control, and water and gas shut-off (Briones et al. 2011; Adewole and Sultan 2014; Adewunmi et al. 2015). The chemical constituents of some of these materials are shown in Tables 2 and 3. From these

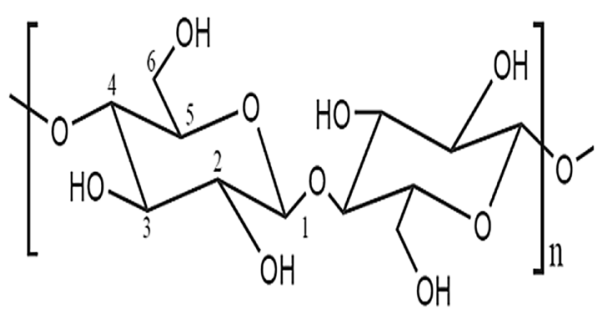

Fig. 1 Molecular structure of cellulose

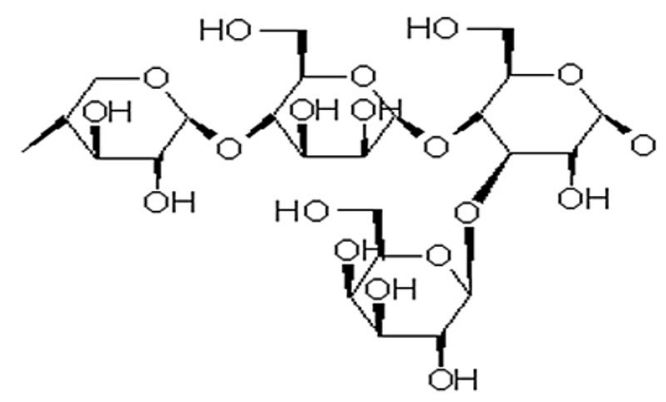

Fig. 2 Molecular structure of hemicellulose

Fig. 3 Molecular structure of one of the dominant building block of lignin

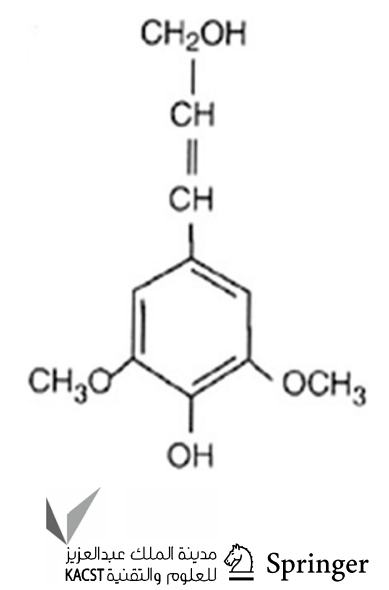


tables, it is shown that cellulose, hemicellulose and lignin are the major constituents of the multicomponent materials. These constituents are some of the most widely used chemicals in oilfield applications. The molecular structures of these major components are shown in Figs. 1,2 and 3.

In addition to what was displayed in Table 2, date contains 98.89 wt \% polyol compounds of cellulose, hemicellulose, and lignin (Briones et al. 2011; Adewole and Sultan 2014) which provides added value to their applications in oilfield operations. The hydrogen bond and other linkages in cellulose provide necessary strength and stiffness for varieties of engineering applications (Chanda and Roy 2009).

Water, which makes up the continuous phase of waterbased drilling mud formulations usually constitute at least 50 volume percent of the entire composition. Oil is also commonly added but in a quantity that is typically not exceeding the amount of the water. Interestingly, most of the bioderived materials also contain a certain amount of fats and oil which can provide added advantages when added to drilling fluid (Adewole and Sultan 2014). Common types of fats that are found in these materials include lauric, myristic, palmitic, stearic, oleic and linoleic (Besbes et al. 2004).

\section{Bio-derived materials for drilling fluid formulation}

In oil field operations, drilling fluids are used for cooling and lubricating the drill bit, cleaning the hole bottom, carrying cuttings to the surface, formation pressure control, and overall improvement of the function of the drill string and tools in the hole (Fink 2012a, b, c). Drilling muds are a special type of drilling fluids that are used to drill most deep wells (Fink 2012a, b, c). Generally, there are two classes of drilling fluids: water-based drilling muds (WBMs) and oilbased drilling muds (OBMs). The choice of drilling fluid to employ while drilling depends on drilling and formation needs. Freshwater muds is a class of WBMs with $\mathrm{pH}$ from 7 to 9.5 , and it includes spud muds, bentonite-containing muds, phosphate-containing muds, organic thinned muds (red muds, lignite muds, lignosulfonate muds), and organic colloid muds.

The ability of drilling fluids to perform their fundamental functions is measured by certain desirable performance characteristic standards. These characteristics include: rheological properties (plastic viscosity, yield value, and gel strengths), fluid loss prevention, stability under various temperature and pressure operating conditions, stability against contaminating fluids (such as salt water, calcium sulfate, cement, and potassium contaminated fluid) (Agbasimalo and Radonjic 2014; Zheng et al. 2015; Sami 2016). In addition, the fluids need to have desirable penetration enhancement characteristics that wet the drill string and keep the cutting
Table 4 Effect of SPI concentration on drilling fluids

\begin{tabular}{llccl}
\hline $\begin{array}{l}\text { SPI concen- } \\
\text { tration }(\%)\end{array}$ & Thickness $(\mathrm{cm})$ & $\begin{array}{l}\text { Filter rate } \\
\left(\mathrm{cm}^{3} / \mathrm{s}\right)\end{array}$ & $\begin{array}{l}\text { Perme- } \\
\text { ability } \\
(\mathrm{mD})\end{array}$ & Porosity $(\%)$ \\
\hline 0.0 & 0.14 & 7.50 & 3.77 & 89.7 \\
1.0 & 0.69 & 16.3 & 40.5 & 94.6 \\
1.5 & 0.65 & 13.8 & 32.3 & 92.5 \\
3.0 & 0.17 & 6.00 & 3.66 & 86.8 \\
6.0 & 0.07 & 2.50 & 0.63 & 72.8 \\
\hline
\end{tabular}

Table 5 Rice husk impact as an additive to drilling fluid

\begin{tabular}{lll}
\hline Weight of rice husk $(\mathrm{g})$ & Fluid loss volume $(\mathrm{mL})$ & $\begin{array}{l}\text { Filter cake } \\
\text { thickness } \\
(\mathrm{mm})\end{array}$ \\
\hline 0.0 & 47.0 & 1.0 \\
5.0 & 42.5 & 1.0 \\
10.0 & 35.0 & 1.5 \\
15.0 & 24.5 & 2.4 \\
20.0 & 16.5 & 3.2 \\
\hline
\end{tabular}

surfaces of the drill bit clean, a high degree of lubricity, and ability to prevent the solids of the formation (such as shales and clays) from swelling. Penetration enhancement is measured in terms of the surface tension of the fluid. Conventionally, WBMs contain viscosifiers, fluid loss control agents, weighting agents, lubricants, emulsifiers, corrosion inhibitors, salts, and $\mathrm{pH}$ control agents. Additives that are used to improve the rheological properties of drilling fluids are polymers such as xanthan gum and partially hydrolyzed polyacrylamide (PHPA). Some of the fluid loss control additives include starch, hydroxypropyl starch, mixtures of starch and polyanionic cellulose (PAC), and carboxymethyl cellulose (CMC).

The use of natural polymers for oil field operations can be traced back to the 1930s. More natural polymers have been investigated in recent years for drilling fluid applications. The use of soy protein (one of the most abundant plant proteins) was investigated by Mei-chun et al. (2015), as soy protein isolate (SPI) at various concentrations. Details of SPI performance in improving drilling fluid properties are summarized in Table 4. At low concentration (1 and $1.5 \mathrm{wt}$ $\%$ ), the addition of SPI was observed to result in thick and loose (highly permeable) filter cake. However, at relatively higher concentration, a thin and low permeability filter cake was formed leading to better drilling fluid with improved fluid loss control property.

In a similar research, rice husk (containing approximately $20 \%$ opaline silica and phenylpropanoid structural polymer, lignin) have also been used in formulating drilling fluid 
(Okon et al. 2014). The blend of silica and lignin compound makes the rice husk to have high resistance to water penetration, thermal and fungal decomposition. The results of using this husk as an additive are shown in Table 5. The addition of rice husk leads to a continuous decrease in the amount of fluid loss but an increase in filter cake thickness. The decrease in the volume of fluid loss is a direct indication of drilling fluid with improved fluid loss control properties. On the other hand, the increase in filter cake thickness, which occurred by the addition of $10 \mathrm{~g}$ of rice husk is bad with respect to drilling fluid performance. It can, therefore, be concluded that rice husk additive is best used at a low concentration to get a balanced fluid loss performance with respect to the volume of fluid loss and filter cake thickness.

According to the International Energy Statistics of the US Energy Information Administration and the OPEC Annual Statistical Bulletin, half of the top ten countries with proven oil reserves as well as largest oil-producing countries are in the Middle East and Africa (EIA 2018; OPEC 2018). The Middle East, and other East Africa and Asian countries are also found to be major producers of some crops from which lignocellulose by-products and wastes are obtained. Saudi Arabia and Egypt, for examples, are the third and first leading producers of date fruits in the world (worldatlas.com). These two countries produce 836,983 and 1,084,529 MT of dates, respectively. Consequently, a huge amount of organic wastes are generated from processing these fruits. Therefore, there are many research efforts geared towards the utilization of these wastes in oil and gas operation.

Adewole and Najimu (2017) investigated the effects date pit additive on water-based drilling fluid. The study involved the effects of date pit chemical compositions, particle size, and date pit concentrations on the fluid density, rheology,

Table 6 Effect of size on filtration properties

\begin{tabular}{lll}
\hline Sample & $\begin{array}{l}\text { Fluid loss after 30 min } \\
(\mathrm{ml})\end{array}$ & $\begin{array}{l}\text { Residue } \\
\text { thickness } \\
\text { (in) }\end{array}$ \\
\hline Pure bentonite & 38.0 & 0.034 \\
$(-) 75 \mu \mathrm{m}$ & 24.8 & 0.035 \\
$(+) 180 \mu \mathrm{m}$ & 28.1 & 0.040 \\
$(+) 710 \mu \mathrm{m}$ & 30.2 & 0.044 \\
\hline
\end{tabular}

filtration and thermal properties of the fluids. The result showed that the rheological and filtration properties of the drilling fluid increased with decreased in particle size of date pit Table 6. The research also showed the chemical composition and method of processing the date pit play a very important role in the performance properties of the ensuing drilling fluid formulation. Moreover, the best performance properties were obtained at date pit concentration of about $10 \mathrm{wt} \%$ for over balance drilling. Above this weight percent, the resulting formulation is better used for under balance drilling due to a drastic reduction in the fluid density.

Amanullah (2016) and Amanullah et al. (2016, 2017) studied the use of date seed as an eco-friendly alternative particulate loss circulation material (LCM). The authors performed filtration property analysis at high temperature and pressure using date seed of size of $150 \mu \mathrm{m}$. In their studies, both laboratory and field trial tests were performed. Their results were compared with commercially available walnut shell-based LCMs. The results of their evaluation showed that the date-seed-based LCMs have similar and sometimes better performance properties than that the commercially available ones.

Moreover, Wajheeuddin and Hossain (2017) also did some investigations on the use of date, grass and grass ash for developing environmental-friendly water-based drilling fluids. They did the elemental, particle size distribution (using sieve analysis and laser particle sizer) and other physico-chemical characterization of these materials. Performance tests of the drilling fluids were done by measuring the rheological and filtration properties of the fluids at different concentrations of the additives (using $300 \mu \mathrm{m}$ particle size). The results of their investigation are presented in Table 7. The result obtained showed significant changes in performance properties between the samples with and without additives and within samples of different additives. The filtration properties of date, grass, and grass-ash-based samples increased by $20 \%, 25 \%$ and $19 \%$, respectively, as compared to samples without additives.

Similarly, the capability of crushed date palm seeds to seal fracture and vugs, hence prevent severe loss circulation was investigated by AlAwad and Fattah (2017). The work looked critically into the limitations of previous studies on date seed application in drilling fluids to bridge the gap between the needed information and what is already
Table 7 Approximated values of performance characteristics $(300 \mu \mathrm{m})$

\begin{tabular}{|c|c|c|c|c|c|c|}
\hline \multirow{2}{*}{$\begin{array}{l}\text { Concentration } \\
(\mathrm{wt} \%)\end{array}$} & \multicolumn{2}{|l|}{ Date } & \multicolumn{2}{|l|}{ Grass } & \multicolumn{2}{|c|}{ Grass Ash } \\
\hline & $\mathrm{AV}(\mathrm{cp})$ & $\mathrm{FV}(\mathrm{ml})$ & AV (cp) & $\mathrm{FV}(\mathrm{ml})$ & $\mathrm{AV}(\mathrm{cp})$ & $\mathrm{FV}(\mathrm{ml})$ \\
\hline 0.25 & 11.00 & 13.85 & 10.30 & 13.50 & 11.00 & 14.25 \\
\hline 1.00 & 11.00 & 13.50 & 11.00 & 11.25 & 11.25 & 12.25 \\
\hline 2.00 & 11.50 & 12.00 & - & - & - & - \\
\hline
\end{tabular}

$A V$ apparent viscosity, $F V$ filtrate volume 
available. A new experimental set up was developed and real core plugs with artificially induced fractures were used. Two different sizes of crushed seeds were used: fine $(0.25-1 \mathrm{~mm})$ and coarse $(1-3 \mathrm{~mm})$. Both high temperature and pressure (HTP) tests were performed. The results of this study revealed that an optimum composition of freshwater mud of $7 \%$ bentonite, $3.5 \%$ fine and $3.5 \%$ coarse date seeds can perfectly seal an artificial fracture of $3 \mathrm{~mm}$ top and $1 \mathrm{~mm}$ bottom created in a sandstone core sample of $38.1 \mathrm{~mm}$ diameter and $38.1 \mathrm{~mm}$ length. It was also shown that the crushed seeds can be used at temperature up to $90{ }^{\circ} \mathrm{C}$ and pressure of 600psi.

Other materials such as carboxymethyl cellulose, guar gum, and starch which are available in abundance and at low cost have also been investigated for drilling fluid formulation. The carboxymethyl cellulose (CMC) is a cellulose derivative with carboxymethyl groups bond to some of the backbone of cellulose. The guar gum belongs to a class of polysaccharide that contained the sugar-galactose and mannose (Bonferoni et al. 1993; Fink 2012a, b, c). Starch is usually used in drilling fluids in its modified forms due to its solubility in water. Starch materials are predominantly used as filtration and rheological properties modifier. The impacts of different types of local (Nigeria) cassavas on the viscosity of drilling mud have been investigated (Ademiluyi et al. 2011). Results of this investigation are shown in Table 8. Samples with the highest amylose content and high water absorption capacity produced drilling fluid with higher viscosity and lower fluid loss.

Three water-soluble cellulosic natural polymers (carboxymethyl cellulose, potato starch, and guar gum) were investigated for application as loss circulation control materials (Alsabagh et al. 2014). The outcome of this investigation revealed that all three materials can be used for controlling the filtration properties of drilling fluids. The addition of these polymers was observed to cause a reduction in the fluid permeability by forming an external filter cake. The improved performance was therefore associated with the ability of these polymers to block the pores that are available for fluid transport. Furthermore, the presence of these

Table 8 Mud samples from different cassava starch (Ademiluyi et al. 2011)

\begin{tabular}{llll}
\hline Different cassava starch & \multicolumn{3}{l}{ Viscosity (at 200 rpm) } \\
\cline { 2 - 4 } & $80^{\circ} \mathrm{F}$ & $120^{\circ} \mathrm{F}$ & $150^{\circ} \mathrm{F}$ \\
\hline TMS 30,572 & 22 & 17 & 15 \\
TME 419 & 23 & 16 & 13 \\
TMS 95/0289 & 23 & 17 & 14 \\
TMS 91/02324 & 23 & 15 & 13 \\
TMS 96/1642 & 23 & 15 & 13 \\
\hline
\end{tabular}

$T M S$ tropical manioc selection, TME tropical manihot esculenta polymers also enhances the rheological properties of the ensued drilling formulation. The optimum concentrations that lead to the best sample formulations are $0.1 \%, 0.3 \%$ and $0.6 \%$ for carboxymethyl cellulose, guar gum, and potato starch, respectively (Alsabagh et al. 2014). It should be noted that the cellulosic materials used in the above investigation have been modified by a carboxymethyl group which made it water-soluble. These authors also investigated some naturally occurring water-insoluble cellulosic materials for loss circulation control additives (Alsabagh et al. 2015). The materials investigated include particles of peanut hulls, bagasse, and sawdust. The effect of the concentration and particle size distribution of the materials on the rheological and filtration properties of drilling mud were evaluated. The authors concluded that all the materials exhibit excellent potential for loss circulation control. Peanut hull additive was found to have the best performance. It was also concluded that all the three additives had a slight effect on the rheological properties of the fluids.

Sugarcane bagasse, a material with fiber-like characteristic, is another material that has been investigated for drilling mud preparation (Kafashi et al. 2017). The addition of sugarcane bagasse to drilling mud was observed to enhance the rheological behavior of the bentonite-based mud. The viscosity of the resulting drilling fluid formulation increased up to about two times the formulation without the bagasse. The enhancement that was observed due to the addition was associated with the long fibers which are present in sugarcane bagasse.

The increase in demand for energy and the need to generate it at lower cost has driven scientists to look into new technologies that can reduce the cost of hydrocarbon production. In drilling, two of the widely used techniques that are used for drilling oil and gas wells are the overbalanced drilling and underbalanced drilling techniques (Fig. 4). The overbalanced drilling (OBD) technique is a conventional drilling technology whereby the drilling fluid is pumped at a pressure higher than the formation pressure. Research efforts discussed so far in this section have been targeted towards drilling fluids that are used for overbalanced drilling.

In underbalanced drilling (UDB), drilling fluid is pumped in such a way that the wellbore pressure is lower than the reservoir formation pressure. For this reason, density-reducing additives are added to conventional drilling fluids. Moreover, lightweight drilling fluids have also been developed as an alternative to the conventional ones for application in the UBD (Wang et al. 2011).

Additives that are commonly used presently include pure gas, gas-liquid mixtures, foams, and oil (both crude and synthetic) (Cunha and Rosa 1998). The use of gas requires special equipment and expertise. In addition, the growing environmental sanctions and safety concerns discourage the 
Fig. 4 Types of drilling techniques (copied with permission from http://www.oilfieldenginee r.com)

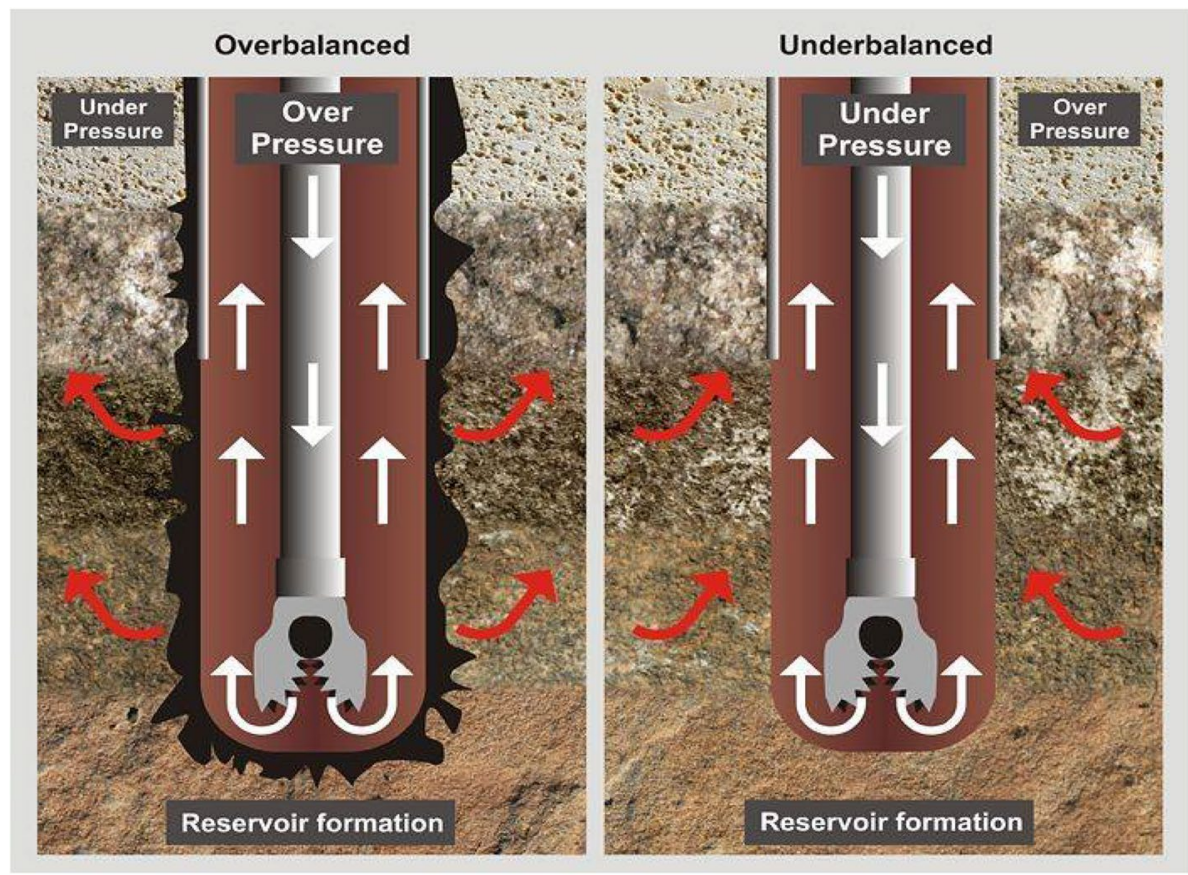

use of oils. This, therefore, makes researchers to focus on developing materials that are environmentally friendly.

Adewole et al. (2018) reported a new date pit-based lightweight drilling fluid for underbalanced drilling. The addition of 1.40 vol\% of modified date pit to bentonite drilling fluid formulation decreased the density of the fluid by $21 \%$. The effect of the additive on other drilling fluid properties such as fluid loss and filter cake thickness were also evaluated. The results obtained from the filtration properties test revealed the formation of a more loosely packed filter cake. This results in an increment in the permeability of the cake and thus reduction in the possibility of formation damage. It will also enhance the flow of hydrocarbons from the formation into the wellbore which is an important requirement in UBD.

Khalil and Jan (2012) evaluated the property of natural polymer-based lightweight drilling fluids using clay, xanthan gum, and starch. The starch used composed of two main polysaccharides (amylase, and amylopectin). The effects the bio-derived polymers on the rheological properties of lightweight drilling formulation were evaluated. Polymer concentration was varied from 0 to $1 \mathrm{wt} \%$ for xanthan gum and 0 to $2 \% \mathrm{w} / \mathrm{v}$ for starch. The authors employed Herschel-Bulkley parameters (yield stress, $\tau_{\mathrm{o}}$; fluid consistency, $\kappa$; index flow, $n$ ) to evaluate the rheological behaviors of the formulation. The results of these rheological parameters are shown in Table 9.

\section{Utilization of renewable resources for chemical enhanced oil recovery (cEOR)}

Oil recovery operations can be subdivided into three stages, namely primary, secondary, and tertiary. Primary production results from the displacement energy that naturally exists in a reservoir. Secondary recovery processes are water flooding and gas injection. Tertiary processes use miscible gases, chemicals and or thermal energy to displace additional oil after the secondary recovery process (Iglauer et al. 2010; Fink 2012a, b, c). In this section, our attention is focused on
Table 9 Rheological properties at different polymer concentrations

\begin{tabular}{llllllll}
\hline $\begin{array}{l}\text { Concentration } \\
(\% \mathrm{w} / \mathrm{v})\end{array}$ & \multicolumn{2}{l}{ Xanthan gum } & & & \multicolumn{2}{l}{ Starch } \\
\cline { 2 - 3 } & $\tau_{0}(\mathrm{pa})$ & $\kappa\left(\mathrm{pa} . \mathrm{S}^{n}\right)$ & $n$ & & $\tau_{0}(\mathrm{pa})$ & $\kappa\left(\mathrm{pa} . \mathrm{S}^{n}\right)$ & $n$ \\
\hline 0.0 & 1.705 & 0.001 & 1.428 & & 0.317 & 0.163 & 0.771 \\
0.5 & 3.879 & 0.462 & 0.643 & & - & - & - \\
1.0 & 10.47 & 0.157 & 0.905 & & 0.901 & 0.216 & 0.728 \\
1.5 & - & - & - & & 3.879 & 0.462 & 0.643 \\
2.0 & - & - & - & & 11.82 & 0.728 & 0.618 \\
\hline
\end{tabular}

$\tau_{\mathrm{o}}$ yield stress, $\kappa$ fluid consistency, $n$ index flow 
Table 10 The categories of available cEOR technologies (Raffa et al. 2016)

\begin{tabular}{ll}
\hline Detailed methods & EOR mechanisms \\
\hline Alkaline flooding & IFT reduction, wettability alteration, mobility control, and emulsion \\
Surfactant flooding & \\
Polymer flooding & \\
ASP flooding & \\
Micellar flooding & \\
\hline
\end{tabular}

IFT interfacial tension chemical EOR. The details of this method are illustrated in Table 10. EOR usually refers to the recovery beyond primary production and water flooding. This is important to facilitate recovery of more than $70 \%$ of the oil which is normally left in the reservoir after primary and secondary methods (Majidaie et al. 2012; Raffa et al. 2016).

Chemical flooding (such as polymer flooding) of oil reservoirs could be one of the most successful methods to increase the oil recovery rate of depleted reservoirs. It can yield a significant increase in percentage recovery by reducing the water production and improving the recovery when compared to the conventional water flooding. Two of the main challenges in the use of chemical method are the cost-effectiveness and the cost sensitivity of polymers to oil prices. Therefore, there is a need to find alternative polymers (which are non-petrochemical based) for EOR applications (Adewole and Sultan 2014). There are two basic categories of polymers and surfactants which are used in the field applications: biopolymers/biosurfactants and synthetic polymers/ surfactants.

The most widely used chemical for polymer flooding is partially hydrolyzed polyacrylamide (HPAM). Many polymers have been investigated as an alternative to this due to its performance limitation in high temperature and high salinity environment. Synthetic as well as naturally occurring polymers have been investigated. For instance, Arjmand et al. (2015) introduced the use of cotton gum as an alternative viscoelastic material in polymer flooding. The performance properties of the gum were evaluated by measuring the viscosity of the gum solution at a different temperature, gum concentration, and salinity conditions. The results of these studies showed a remarkable increase in viscosity and better resistance to high salinity.

In an attempt to test natural surfactant and polymers for applications in EOR, Samanta et al. (2011) characterized guar gum and surfactant extracted from soap nutshell using interfacial and rheological properties. A sand pack flooding test was also performed using three sets of experiment: polymer (P), surfactant-polymer (SP) and alkaline-surfactant-polymer (ASP). The critical concentrations of each of these systems were marked based on the results of their rheological and interfacial properties. The experimental results obtained from the test showed that the naturally occurring material possesses some potentials for EOR
Table 11 Effect of date pit powder on the viscosity of surfactant formulation at $38^{\circ} \mathrm{C}$

\begin{tabular}{ll}
\hline $\begin{array}{l}\text { Weight of date } \\
\text { pit powder }(\mathrm{g})\end{array}$ & Viscosity $(\mathrm{cP})$ \\
\hline 0.0 & 1.0 \\
0.8 & 2.0 \\
1.8 & 3.0 \\
2.5 & 5.0 \\
5.0 & 10 \\
6.5 & 23 \\
\hline
\end{tabular}

operations. The results were $15.76,16.4$ and $24.12 \%$ of original oil in place (OOIP) for P, SP, and ASP, respectively.

The potential of date pit for EOR was investigated by Adewole and Sultan (2014). The authors evaluated the capability of date pit for mobility control. Thus, the effect of date pit powder on the viscosity of surfactant formulation was investigated. Table 11 contains the results of the investigation. It was observed that date powder (in aqueous $\mathrm{NaOH}$ solution) possesses some level of viscosity enhancement capability which is useful for EOR application.

Some other research works have been published on the use of date pit for EOR applications. For example, the use of date molasses as a carbon source for producing biosurfactant was investigated by Al-Bahry et al. (2013) and Al-Wahaibi et al. (2014). In both cases, the biosurfactants produced exhibit a strong capability to reduce surface and interfacial tension. Moreover, the biosurfactants also showed significant stability under a wide range of EOR operating conditions (such as temperatures, $\mathrm{pH}$ and salt concentrations). Using the biosurfactants produced by Bacillus subtilis B20, an additional 9.7\% oil was recovered based on core-flood studies. The biosurfactants prepared with Bacillus subtilis strain B30 enhanced light oil recovery by $17-26 \%$ and heavy oil recovery by $31 \%$ based on the results of coreflood studies.

A considerable amount of oil and gas reserves are found in carbonate reservoirs (Bortolotti et al. 2010). One of the challenges in producing oil from this class of reservoirs is the presence of excessive natural fractures. Therefore, the early breakthrough of water during flooding leaves the majority of residual oil un-swept (Liu et al. 2015). This challenge can be solved by sealing the natural fractures and thereby diverting the water to oil-rich areas. Microbial biomass has been 
Table 12 Effect of date pit loading on permeability and selectivity (Adewole 2016)

\begin{tabular}{lllllll}
\hline Sample & $\% \mathrm{wt}$ & $\mathrm{He}$ & $\mathrm{H}_{2}$ & $\mathrm{~N}_{2}$ & $\mathrm{CH}_{4}$ & $\mathrm{CO}_{2}$ \\
\hline DP-PS-0 & 0.00 & 600.454 & 633.873 & 230 & 318.229 & 240.292 \\
DP-PSF-2 & 2.00 & 30.768 & 20.339 & 8.461 & 11.072 & 13.957 \\
DP-PSF-5 & 5.00 & 151.264 & 213.773 & 76.165 & 115.697 & 94.949 \\
DP-PSF-10 & 10.00 & 1130.918 & 1741.240 & 547.787 & 705.246 & 445.658 \\
\hline
\end{tabular}

proposed as one of the materials that can be used to achieve this. The use of simple carbohydrate and date pit molasses as cheap feed substrate to produce biomass for improving the sweep efficiency has been investigated (Al-Hattali 2012; AlHattali et al. 2012). The results of these studies showed that sweep efficiency can be improved by up to $30 \%$ production from residual oil using the produced biomass.

\section{Water and gas control in oilfield using natural polymer}

Whenever water production exceeds the economic limits of a given oil or gas field, there is often the need to develop a process by which produced water is reduced. Petroleum industry spends billions of dollars every year to process excessive produced water. Moreover, water causes corrosion, scale and produced water treatment requires the construction of large downstream handling facilities (Al-Muntasheri 2012).

Several types of materials and methods are used for water and gas control. One of the most commonly used set of materials is polymer gels. They are used as water-relative permeability modifier (RPM), and sealant. RPMs usually reduce the relative permeability of water without affecting the permeability of oil. The sealant type of gels seals all the fluids by creating a barrier. Moreover, fractures, highpermeability channels and other heterogeneities present in reservoirs are very likely to provide preferential paths to the fluid and therefore cause a premature breakthrough. A common way to mitigate this problem and to maximize the production from the reservoir is to place sealants or blocking agents in such flow paths. Polymer gels and other types of conformance materials are permeability reducing agents that can fill fractures and high permeability channels to reduce fluid production (Kabir 2001).

Natural polymers could play a very important part in improving the performance of polymer gels. Adewunmi et al. (2015) investigated the potentials of cross-linked polyacrylamide composite hydrogels embedded with date seed powder for water control in oil reservoirs. The authors examined the effect of date pit on the rheological behavior, morphological and structural properties of the hydrogels. The characterization results showed that the surface of the hydrogels filled with various concentrations of date pit was smooth, homogeneous and dense.
Another challenge often faced by operators in the oilfield is the co-production of associated gas from oil wells. This is particularly worrisome if the extra gas does not have readily available access to a market, thereby making disposal becomes the only option. Most of the disposal solutions (such as flaring, well injection or liquid conversion) are environmentally unfriendly, technically challenging, and expensive. An alternative method commonly employed by oilfield operators is the gas shut-off. To shut off unwanted gas production to optimize the overall reservoir recovery, a wide range of technology is employed including cased-hole wireline, chemical treatments, and thru-tubing services. For problem which resides near the wellbore, mechanical solutions within the thru-tubing services portfolio often provide the best option. Studies were conducted by Adewole (2016) on gas transport properties of date pit/polysulfone composite for some associated gas components including $\mathrm{CO}_{2}, \mathrm{CH}_{4}$, $\mathrm{N}_{2}$, He, and $\mathrm{H}_{2}$ gases. The tested composite membrane materials were prepared with $2-10 \mathrm{wt} \%$ date pit micro-sized particles. Gas shut-off performance of the membranes was done using high-pressure gas permeation. The resulting composite showed the highest decrease in overall gas permeability of $96 \%$ with $2 \mathrm{wt} \%$ loading of date pit particles as compared to pure polysulfone membrane (Table 12). Thus, this composite possesses some potential for innovative fluid control technology which can lead to the most significant cost reduction and improved oil production. This is especially important in solving the gas flaring related environmental pollution issues in the oil-producing countries around the world.

Generally, the results of Table 12 showed that date pitbased membrane composite can be used for gas shut-off at low concentration (up to $2 \mathrm{wt} \%$ ) while at high concentration, the resulting membrane is better suited for natural gas processing.

\section{Conclusion and recommendation for future work}

Naturally occurring macromolecular materials are among the abundantly available resources whose by-products and wastes are underutilized. This review has described the research efforts that have been done to provide alternative applications for these naturally occurring multicomponent materials. Research outcomes on the use of these 
materials in the oilfield operations such as drilling, enhanced oil recovery, gas processing and control of water and gas production were presented. Based on the results of all the research published so far, the plant-based polymers exhibit promising potentials in oilfield operations. Therefore, it can be concluded that integrating the use of these resources with the oilfield chemical production will help in creating a smart way of managing its wastes. It will also help in reducing environmental pollution resulting from oilfield chemicals disposal after usage. It was recommended that research collaboration between the academic and the industry should begin as soon as possible. This will allow for field test and deployment of the already developed natural polymer-based products. Research efforts in the area of techno-economic analysis are also important from the commercialization point of view.

Acknowledgements The authors gratefully acknowledge the financial support received from College of Petroleum Engineering and Geosciences under Grant number SF17004.

Open Access This article is distributed under the terms of the Creative Commons Attribution 4.0 International License (http://creativeco mmons.org/licenses/by/4.0/), which permits unrestricted use, distribution, and reproduction in any medium, provided you give appropriate credit to the original author(s) and the source, provide a link to the Creative Commons license, and indicate if changes were made.

\section{References}

Aboulrous AA, Mahmoud T, Alsabagh AM, Abdou MI (2016) Application of natural polymers in engineering. In: Olatunji O (ed) Natural polymers: industry techniques and applications. Springer International Publishing, Cham 185-218

Ademiluyi T, Joel OF, Amuda AK (2011) Investigation of local polymer (cassava starches) as a substitute for imported sample in viscosity and fluid loss control of water based drilling mud. ARPN J Eng Appl Sci 6(12):43-48

Adewole JK (2016) Transport properties of gases through integrally skinned asymmetric composite membranes prepared from date pit powder and polysulfone. J Appl Polym Sci 133(28):1-8

Adewole JK, Najimu MO (2017) A study on the effects of date pitbased additive on the performance of water-based drilling fluid. J Energy Res Technol 140(5):052903-052903

Adewole JK, Sultan AS (2013) Synthesis and performance evaluation of date pit based surfactant-polymer formulation for enhanced chemical flooding. SPE Saudi Arabia section technical symposium and exhibition. Society of Petroleum Engineers, Al-Khobar

Adewole JK, Sultan AS (2014) A study on processing and chemical composition of date pit powder for application in enhanced oil recovery. Defect Diffusion Forum 353:79-83

Adewole JK, Najimu MO, Adewunmi AA (2018) Date pit-based additive as density reducing agent in underbalanced drilling. SPE/ IADC Middle east drilling technology conference and exhibition. UAE, Abu Dhabi

Adewunmi AA, Ismail S, Sultan AS (2015) Laboratory scale study on rheological behavior, morphological and structural properties of crosslinked polyacrylamide composite hydrogels embedded with date seed powder. J Appl Polym Sci 132(28)

Agbasimalo N, Radonjic M (2014) Experimental study of the impact of drilling fluid contamination on the integrity of cement-formation interface. J Energy Res Technol 136(4):042908-042908

AlAwad MNJ, Fattah KA (2017) Superior fracture-seal material using crushed date palm seeds for oil and gas well drilling operations. J King Saud Univ Eng Sci 31:97-103

Al-Bahry SN, Al-Wahaibi YM, Elshafie AE, Al-Bemani AS, Joshi SJ, Al-Makhmari HS, Al-Sulaimani HS (2013) Biosurfactant production by Bacillus subtilis B20 using date molasses and its possible application in enhanced oil recovery. Int Biodeterior Biodegrad 81(Supplement C):141-146

Al-Hattali R (2012) Microbial biomass for improving sweep efficiency in fractured carbonate reservoir using date molasses as renewable feed substrate. Society of Petroleum Engineers

Al-Hattali RR, Al-sulaimani HS, Al-wahaibi YM, Al-Bahry S, Elshafie A, Al-Bemani AS, Joshi S (2012) Improving sweep efficiency in fractured carbonate reservoirs by microbial biomass. Society of Petroleum Engineers

Al-Muntasheri GA (2012) Conformance control with polymer gels: what it takes to be successful. Arab J Sci Eng 37(4):1131-1141

Alsabagh AM, Abdou MI, Khalil AA, Ahmed HE, Aboulrous AA (2014) Investigation of some locally water-soluble natural polymers as circulation loss control agents during oil fields drilling. Egypt J Pet 23(1):27-34

Alsabagh AM, Abdou MI, Ahmed HE-s, Khalil AA-s, Aboulrous AA (2015) Evaluation of some natural water-insoluble cellulosic material as lost circulation control additives in water-based drilling fluid. Egypt J Pet 24(4):461-468

Al-Wahaibi Y, Joshi S, Al-Bahry S, Elshafie A, Al-Bemani A, Shibulal B (2014) Biosurfactant production by Bacillus subtilis B30 and its application in enhancing oil recovery. Colloids Surf B 114(Supplement C):324-333

Amanullah M (2016) Characteristics, behavior and performance of arc plug-a date seed-based sized particulate LCM. Society of Petroleum Engineers

Amanullah M, Ramasamy J, Al-Arfaj MK, Aramco S (2016) Application of an indigenous eco-friendly raw material as fluid loss additive. J Petrol Sci Eng 139:191-197

Amanullah M, Al-Arfaj M, Gadalla A, Saleh R, El-Habrouk I, AlDhafeeri B, Khayat A (2017) Date seed-based particulate LCM "ARC plug"-its development, laboratory testing and trial test results. Society of Petroleum Engineers

Arjmand O, Zarekhafri A, Mousavi MS (2015) Introduction of cotton gum as a natural polymer to enhance oil recovery. Int J Chem Pet Sci 4(2):26-33

Besbes S, Blecker C, Deroanne C, Drira N-E, Attia H (2004) Date seeds: chemical composition and characteristic profiles of the lipid fraction. Food Chem 84(4):577-584

Biswas A, Kim S, Selling GW, Cheng HN (2014) Conversion of agricultural residues to carboxymethylcellulose and carboxymethylcellulose acetate. Ind Crops Prod 60(Supplement C):259-265

Bonferoni MC, Rossi S, Tamayo M, Pedraz JL, Dominguez-Gil A, Caramella C (1993) On the employment of $\lambda$-carrageenan in a matrix system. I. Sensitivity to dissolution medium and comparison with $\mathrm{Na}$ carboxymethylcellulose and xanthan gum. J Control Release 26(2):119-127

Bortolotti V, Macini P, Srisuriyachai (2010) Wettability index of carbonatic reservoirs and EOR: laboratory study to optimize alkali and surfactant flooding. CPS/SPE International Oil and Gas Conference and Exhibition, Beijing

Briones R, Serrano L, Younes RB, Mondragon I, Labidi J (2011) Polyol production by chemical modification of date seeds. Ind Crops Prod 34(1):1035-1040 
Chanda M, Roy SK (2009) Industrial polymers, specialty polymers, and their applications. CRC Press Taylor \& Francis Group, Boca Raton

Cunha JC, Rosa FSN (1998) Underbalanced drilling technique improves drilling performance-a field case history. Society of Petroleum Engineers

EIA (2018) US energy information administration, international energy statistics. Retrieved January 3rd 2018, 2018, from http://www. eia.gov

Fink JK (2012a) Chapter 1—drilling muds. Petroleum engineer's guide to oil field chemicals and fluids. Gulf Professional Publishing, Boston, 1-59

Fink JK (2012b) Chapter 2-fluid loss additives. Petroleum engineer's guide to oil field chemicals and fluids. Gulf Professional Publishing, Boston, 61-123

Fink JK (2012c) Chapter 16-enhanced oil recovery. Petroleum engineer's guide to oil field chemicals and fluids. Gulf Professional Publishing, Boston, 459-517

Fiorelli J, Gomide C, Lahr F, do Nascimento M, de Lucca Sartori D, Ballesteros J, Bueno S, Belini U (2014) Physico-chemical and anatomical characterization of residual lignocellulosic fibers. Cellulose 21(5):3269-3277

Gandini A (2008) Polymers from renewable resources: a challenge for the future of macromolecular materials. Macromolecules 41(24):9491-9504

Iglauer S, Wu Y, Shuler P, Tang Y, Goddard WA (2010) New surfactant classes for enhanced oil recovery and their tertiary oil recovery potential. J Petrol Sci Eng 71(1-2):23-29

Kabir AH (2001) Chemical water \& gas shutoff technology-an overview. Society of Petroleum Engineers

Kafashi S, Rasaei M, Karimi G (2017) Effects of sugarcane and polyanionic cellulose on rheological properties of drilling mud: an experimental approach. Egypt J Pet 26(2):371-374

Khalil M, Mohamed Jan B (2012) Herschel-Bulkley rheological parameters of a novel environmentally friendly lightweight biopolymer drilling fluid from xanthan gum and starch. J Appl Polym Sci 124(1):595-606

Kraak A (1992) Industrial applications of potato starch products. Ind Crops Prod 1(2):107-112

Li Y, Liu Y, Chen W, Wang Q, Liu Y, Li J, Yu H (2016) Facile extraction of cellulose nanocrystals from wood using ethanol and peroxide solvothermal pretreatment followed by ultrasonic nanofibrillation. Green Chem 18(4):1010-1018

Liu D, Zhong X, Guo J, Shi X, Qi Y, Qi Y, Qi Y (2015) Enhanced oil recovery from fractured carbonate reservoir using membrane technology. J Petrol Sci Eng 135(Supplement C):10-15

Majidaie S, Muhammad M, Tan IM, Demiral B, Lee SYC (2012) Non-petrochemical surfactant for enhanced oil recovery. SPE EOR conference at oil and gas West Asia, Muscat. Society of Petroleum Engineers

Mohlala LM, Bodunrin MO, Awosusi AA, Daramola MO, Cele NP, Olubambi PA (2016) Beneficiation of corncob and sugarcane bagasse for energy generation and materials development in Nigeria and South Africa: a short overview. Alex Eng J 55(3):3025-3036

Murr LE (2015) Examples of natural composites and composite structures. In: Handbook of materials structures, properties, processing and performance. Springer International Publishing, Cham, 425-449

Olatunji O (2016) Classification of natural polymers. In: Olatunji O Natural polymers: industry techniques and applications. Springer International Publishing, Cham, 1-17

OPEC (2018) OPEC Annual Statistical Bulletin. Retrieved 3rd January 2018, 2018, from http://www.opec.org/opec_web/en/publi cations $/ 202 . h t m$

Raffa P, Broekhuis AA, Picchioni F (2016) Polymeric surfactants for enhanced oil recovery: a review. J Petrol Sci Eng 145:723-733

Samanta A, Ojha K, Mandal A (2011) The characterization of natural surfactant and polymer and their use in enhanced recovery of oil. Pet Sci Technol 29(7):765-777

Sami NA (2016) Effect of magnesium salt contamination on the behavior of drilling fluids. Egypt J Pet 25(4):453-458

Sheldon RA (2014) Green and sustainable manufacture of chemicals from biomass: state of the art. Green Chem 16(3):950-963

Singh P, Kumar R, Sabapathy SN, Bawa AS (2008) Functional and edible uses of soy protein products. Compr Rev Food Sci Food Saf 7(1):14-28

Sluiter JB, Ruiz RO, Scarlata CJ, Sluiter AD, Templeton DW (2010) Compositional analysis of lignocellulosic feedstocks. 1. Review and description of methods. J Agric Food Chem 58(16):9043-9053

Templeton DW, Scarlata CJ, Sluiter JB, Wolfrum EJ (2010) Compositional analysis of lignocellulosic feedstocks method uncertainties. J Agric Food Chem 2:58

Vassilev SV, Baxter D, Andersen LK, Vassileva CG (2010) An overview of the chemical composition of biomass. Fuel 89(5):913-933

Wajheeuddin M, Hossain ME (2017) Development of an environmentally-friendly water-based mud system using natural materials. Arab J Sci Eng

Wang X, Zhang Y, Lv F, Shen B, Zhang R, Zhou F, Chu PK (2011) Cross-linked polystyrene microspheres as density-reducing agent in drilling fluid. J Petrol Sci Eng 78(2):529-533

Zheng Y, She C, Yao K, Guo X, Zhang H, Yang T, Li M (2015) Contamination effects of drilling fluid additives on cement slurry. Nat Gas Ind B 2(4):354-359

Publisher's Note Springer Nature remains neutral with regard to jurisdictional claims in published maps and institutional affiliations. 